\title{
Menuju Desa Mandiri Dengan Pemberdayaan Kelompok Tani Melalui Budidaya Jamur Tiram Di Desa Sukarara Kecamatan Sakra Barat Lombok Timur
}

\author{
Baiq Salkiah, Meiyanti Widyaningrum*, Samsul Bahri \\ Fakultas Keguruan dan IImu Pendidikan,Universitas Nahdlatul Wathan Mataram \\ Corresponding author email: meiyanti0905@gmail.com
}

\section{Diterima: April 2019; Revisi: April 2019; Diterbitkan: Mei 2019}

\begin{abstract}
Abstrak
Tujuan dari kegiatan ini adalah pelatihan kelompok tani budidaya jamur tiram di desa sukaraja sebagai upaya menuju desan mandiri. Mitra dalam kegiatan ini adalah kelompok tani desa sukaraja kecamatan sakra barat. Metode kegitaan dengan trasfer pengetahuan dan teknologi. Hasil pengabdian yang telah di capai meliputi: (1) Terlaksananya penyuluhan; (2) Terbentuknya dua kumbung budidaya jamur tiram; (3) Memotivasi masyarakat untuk merintis wirausaha baru dan membuka peluang kerjadi bidang pembudidayaan Jamur Tirambagi masyarakat Desa Sukarara sehingga dapat meningkatkan kesejahteraan hidup masyarakat; (4) Tersedianya buku pedoman budidayaan Jamur Tiram. Kegiatan pendampingan perlu dilakukan secara kontinu agar mitra dapat madiri dalam pembudidayaan.
\end{abstract}

Kata Kunci: Budidaya; Jamur Tiram; Desa Mandiri

\section{Towards an Independent Village with Empowerment of Farmer Groups through Oyster Mushroom Cultivation in Sukarara Village, West Sakra District, East Lombok}

\begin{abstract}
The purpose of this activity is an oyster mushroom farmer training group in Sukaraja village as an effort towards an independent design. Partners in this activity are farmer groups in Sukaraja village, West Sakra sub-district. Activity method with the transfer of knowledge and technology. The results of service that have been achieved include: (1) Implementation of counseling; (2) Two oyster mushroom cultivation centers were formed; (3) Motivate the community to pioneer new entrepreneurs and open up opportunities for work in the Tirambagi Mushroom cultivation for the people of Sukarara Village so as to improve the welfare of the community; (4) The availability of a new book on Oyster Mushroom cultivation. Assistance activities need to be carried out continuously so that partners can participate in cultivation.
\end{abstract}

\section{Keywords: Cultivation; Oyster mushroom; Independent Village}

How to Cite: Salkiah, B., Widyaningrum, M., \& Bahri, S. (2019). Menuju Desa Mandiri Dengan Pemberdayaan Kelompok Tani Melalui Budidaya Jamur Tiram Di Desa Sukarara Kecamatan Sakra Barat Lombok Timur. Lumbung Inovasi: Jurnal Pengabdian kepada Masyarakat, 4(1), 23-30. doi:https://doi.org/10.36312/linov.v4i1.440

\section{PENDAHULUAN}

Sukarara memiliki lima dusun yaitu dusun Repok, dusun Suangi, dusun Sukarara merupakan salah satu desa yang terletak di Kecamatan Sakra Barat, Kabupaten Lombok Timur, Provinsi Nusa Tenggara Barat. Detara, dusun Sukarara Selatan, dan dusun Tangar. Desa Sukarara masuk pada daerah topografi datar dengan ketinggian 300-400 DPL/Meter. Curah hujannya 1.190 dengan suhu udara 25-30. Adapun untuk luasan wilayahnya 544,58 Ha. Batas-batas desa dan jarak antara tempuhnya sebagai berikut: Sebelah utara berbatasan dengan Desa Suwangi Kecamatan Sakra dan Desa Pejaring Kecamatan Sakra Barat. 
Masyarakat Sukarara pada umumnya bekerja sebagai petani dan buruh pertanian. Secara geografis, letak desa Sukarara sangat dekat dengan Bendungan Pandan Dure. Keberadaan Bendungan Pandan Dure ini berdampak langsung pada kondisi pertanian masyarakat di desa Sukarara. Kebutuhan air masyarakat di desa Sukarara selalu terpenuhi sepanjang tahun. Hal inilah yang menyebabkan desa Sukarara sangat potensial untuk lahan pertanian. Salah satu potensi yang dapat dikembangkan selain lahan pertanian adalah budidaya Jamur Tiram, disebabkan oleh faktor kesuburan tanah. Disekitar desa Sukararajuga terdapat beberapa penjual kayu bangunan yang banyak menghasilkan serbuk gergaji sebagai media utama budidaya Jamur Tiram. Salah satu tempat penjual dan pemasok kayu terbesar di Lombok Timur bagian Selatan adalah KP Saw Mile. Disamping itu, desa Sukarara juga terdapat beberapa tempat penggilingan padi karena memang masyarakat Sukarara sebagian besar bekerja sebagai petani yang produk unggulannya berupa padi sehingga menghasilkan banyak jerami dan dedak, dimana jerami dan dedak ini juga digunakan sebagai campuran media budidaya Jamur Tiram.

Jamur tiram merupakan jamur yang dapat dikonsumsi dan hidup secara alami di pohon-pohon kayu yang sudah lapuk. Jamur tiram dikenal pula dengan nama popular Oyster mushroom (Sunarmi \& Suparto, 2018; Achmad, dkk. 2011). Jamur tiram ini termasuk kedalam jamur yang bayak dibudidayakan di dunia bahkan banyak dibudidayakan di Indonesia karena sesuai dengan ikilim yang dibutuhkan untuk hidup. Jamur tiram memiliki nilai yang cukup tinggi sehingga masyarakat cendrung membudidayakan jamur ini, selain itu pembudidayaan juga cukup mudah dan praktis.

Syarat tumbuh jamur tiram adalah lingkungan yang sejuk (suhu $28-32^{\circ} \mathrm{C}$ ) dan lembab. Suhu yang terlalu dingin menyebakan miselium tumbuh lambat. Sedangkan suhu yang teralau panas dapat membuat miselium jamur tiram mati. Syarat berikutnya adalah lingkungan yang lembab (bukan pengap) dengan kadar uap air berkisar antara $80 \%-90 \%$. Jika kadar uap air di bawah $60 \%$ miselium dapat kering/mati. Sebaliknya jika terlalu tinggi dapat menyebabkan baglog kontaminasi bahkan busuk (Ismail, 2018).

Selain potensi lokal yang melimpah letak geografis dengan suhu berkisar 25-30 cukup medukung pertumbuhan jamur tiram. Suryani \& Carolina (2017) menyatakan temperatur yang cocok untuk budidaya jamur tiram putih adalah $22-28{ }^{\circ} \mathrm{C}$ dengan kelembaban $60-90 \%$, sedangkan temperatur pada pembentukan tubuh buah berkisar 15-30 ${ }^{\circ} \mathrm{C}$ dengan kelembaban 80-90.

Melihat kondisi ini maka memungkinkan dan sangat mendukung bisa dikembangkan budidaya Jamur Tiram di desa Sukarara. Dengan kegiatan ini diharapkan dapat mengurangi pengangguran dan sekaligus bisa menjadi sarana untuk meningkatkan pendapatan masyarakat desa Sukarara. Tujuan dari kegitan pengabdian ini adalah pelatihan kelompok tani budidaya jamur tiram di desa sukaraja sebagai upaya menuju desan mandiri.

\section{METODE PELAKSANAAN}

\section{Mekanisme pelaksanaan kegiatan KKN-PPM;}

a) Mendata dan memverifikasi mahasiswa Universitas Nahdlatul Wathan (UNW) Mataram, FKIP UNW Mataram yang akan menempuh mata kuliah KKN-PPL Terpadu dengan syarat telah menempuh 106 SKS dengan minimal IPK 2,75.

b) Memberikan pembekalan materi KKN-PPM kepada mahasiswa sebagai peserta dengan pendampingan oleh Dosen Pembimbing Lapangan (DPL).

c) Melakukan survey lokasi KKN-PPM oleh Tim dan LPPM Universitas Nahdlatul Wathan (UNW) Mataram.

d) Melakukan acara penerimaan mahasiswa KKN-PPM Universitas Nahdlatul Wathan (UNW) Mataram di Desa Sukarara Kecamatan Sakra Barat Kabupaten Lombok Timur NTB.

e) Memberikan pengetahuan kepada masyarakat (unsur organisasi desa dan perwakilan masyarakat umum) Desa Sukarara tentang tujuan program KKN-PPM Universitas Nahdlatul Wathan (UNW) Mataram.

f) Berdiskusi antara masyarakat desa Sukarara dengan mahasiswa besertaDPL untuk membahas tentang program Pelatihan dan Pembinaan Lapangan.

g) Merumuskan pola pelaksanaan program Pelatihan dan Pembinaan Lapangan dengan mengikut sertakan masyarakat sebagai bagian penanggung jawab setiap kegiatan. 
h) Melakukan Pelatihan dan Pembinaan Lapangan dalam budidaya Jamur Tiram

i) Melakukan acara penarikan mahasiswa KKN-PPM Universitas Nahdlatul Wathan (UNW) Mataram dari Desa Sukarara Kecamatan Sakara Barat Kabupaten Lombok Timur Provinsi NTB.

Materi persiapan dan pembekalan KKN-PPM yang perlu diberikan kepada mahasiswa

1. Memberikan materi budidaya Jamur Tiram oleh Tim Dosen program KKN-PPM.

2. Memberikan materi biografi Daerah sasaran KKN-PPM oleh Tim Survey Lokasi KKN-PPM.

3. Pembekalan mahasiswa KKN-PPM dilaksanakan oleh Lembaga Penelitiandan Pengabdian Masyarakat (LPPM) Universitas Nahdlatul Wathan (UNW)Mataram dan Tim pelaksana ProgramKKN-PPM ini.

\section{HASIL DAN PEMBAHASAN}

Kegiatan KKN-PPM tentang budidaya jamur tiram bermitra dengan masyarakat desa sukaraja kecamatan sakra barat. Tujuan dari kegitan pengabdian ini adalah pelatihan kelompok tani budidaya jamur tiram di desa sukaraja sebagai upaya menuju desan mandiri. Untuk mencapai tujuan yang ditargetkan maka dalam pelaksanaan KKN-PPM dilakukan denganbeberapa tahapan antara lain;

a. Menghubungi Mitra Masyarakat Sasaran.Kegiatan ini dilaksanakan oleh tim pengabdi dan tim mahasiswa KKN Universitas Nahdlatul Wathan (UNW) Mataram yang ditempatkan di lokasi masyarakat sasaran.

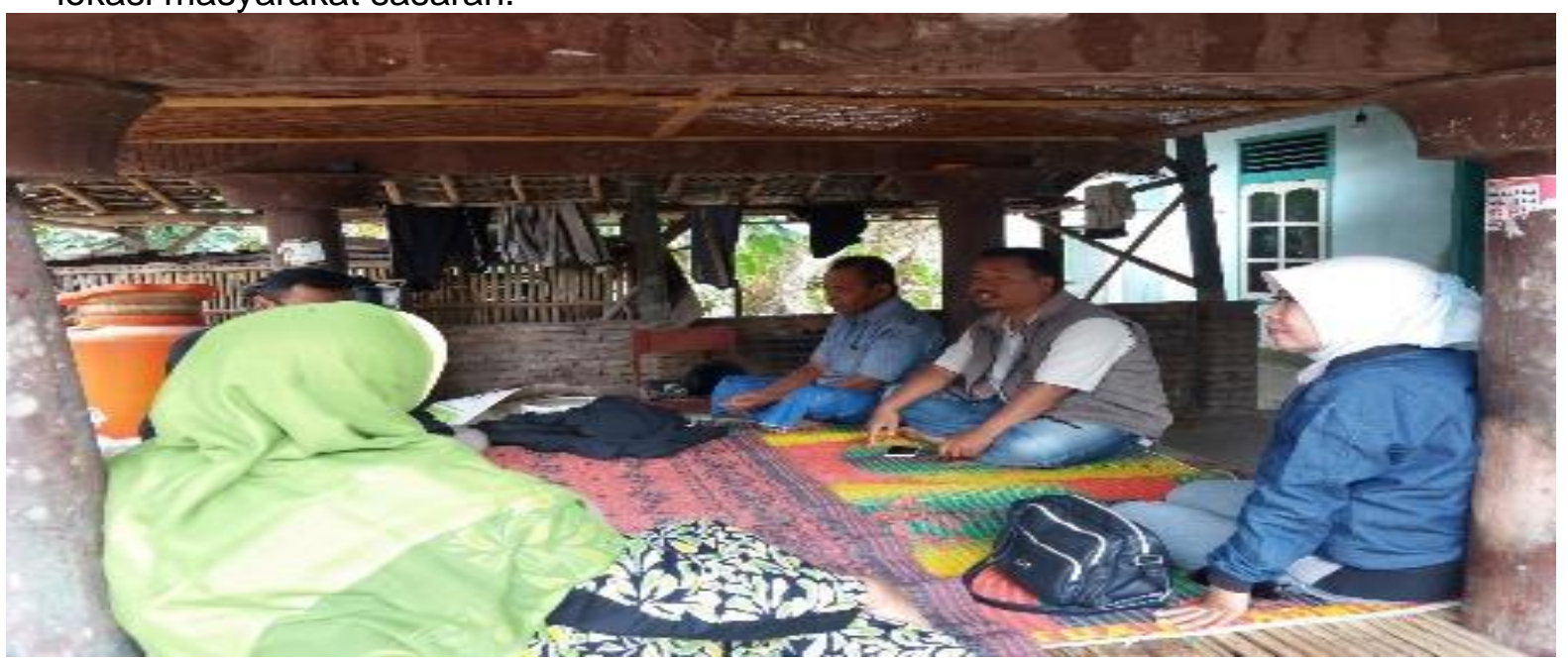

Gambar 1. Kunjungan Ke Desa Sukarara

b. Sosialisasi. Sosialisasi terdapat beberapa kegiatan yaitu: Sebelum pelaksanaan pembudidayaan Jamur Tiram ini dilakukan, maka langkah pertama yang diupayakan adalah melakukan sosialisasi kepada masyarakat sasaran. Langkah-langkah yang dilakukan adalah: (1) Menghubungi masyarakat Desa Sukarara untuk mengetahui secara dekat kebutuhan dan harapan masyarakat (2) Menghubungi dan menjalin komunikasi dengan masyarakat sasaran untuk melaksanakan penyuluhan budidaya Jamur Tiram di Desa Sukarara, dalam hal ini warga Desa Dusun Repok, dan Dusun Sukarara Utara, pemuka masyarakat dan tokoh agama. (3) Mengadakan pelatihan budidaya Jamur Tiram.

c. Pengarahan tim dan Sosialisasi Penyuluhan Jamur Tiram ke Mahasiswa KKN. Pengarahan mahasiswa KKN yang terlibat dalam kegiatan ini diberi pembekalan berupa pematerian pembudidayaan Jamur Tiram oleh DPL dengan total mahasiswa KKN yaitu 25 orang dilaksanakan di Universitas Nahdlatul Wathan (UNW) Mataram dan dilanjutkan dengan praktik pembuatan media Jamur Tiram di posko KKN mahasiswa. Hasil yang dicapai mahasiswa tim KKN memiliki keterampilan dalam membuat media Jamur Tiram, mempraktikkan membuat media Jamur Tiram di posko KKN dan dapat memiliki kepercayaan diri untuk dipraktikkan ke masyarakat. 


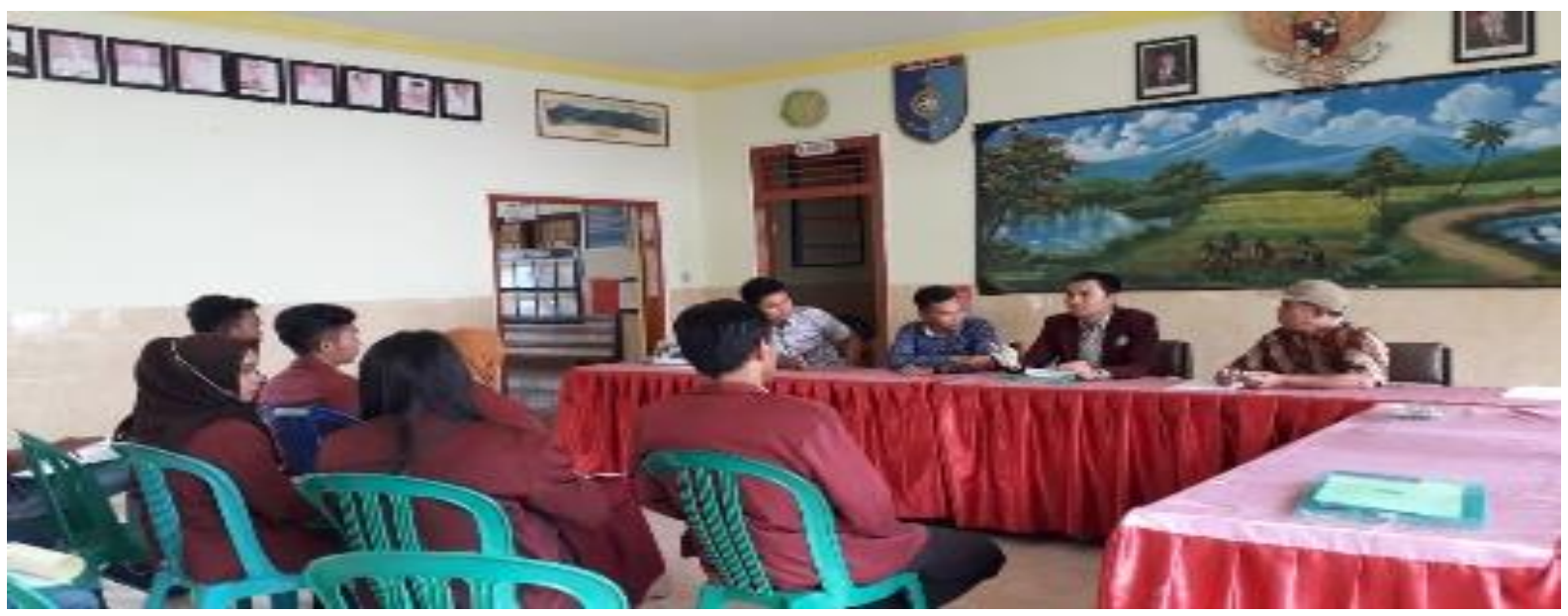

\section{Gambar 2. Pengarahan Oleh Tim}

d. Penyuluhan Budidaya Jamur Tiram. Penyuluhan melibatkan tim pengabdi dengan materi pengenalan budidaya Jamur Tiram, praktik pembuatan media Jamur Tiram, praktik perawatan Jamur Tiram, praktik pemanenan Jamur Tiram dan praktik pemasaran Jamur Tiram. Pemberian materi dilakukan oleh tim pengabdi. Penyuluhan ini juga membagikan beberapa properti kepada perkumpulan warga untuk digunakan dalam kegiatan budidaya Jamur Tiram.

e. Pendampingan Budidaya Jamur Tiram. Pendampingan dilakukan untuk mendata warga yang berminat dan warga yang telah mencoba dan akan mencoba. Proses pendampingan dilaksanakan berupa penjelasan ulang kegiatan budidaya Jamur Tiram untuk warga yang belum paham sepenuhnya, pemberian bahan yang dibutuhkan untuk merintis usaha Jamur Tiram dan perintisan pendirian budidaya Jamur Tiram.

f. Penyusunan buku panduan pelatihan pengelolaan budidaya Jamur Tiram.

Dalam pembudidayaan Jamur Tiram, ada beberapa tahapan yang harus diperhatikan, yakni berupa persiapan media, pencampuran media, pengantongan, sterilisasi, inokulasi bibit, inkubasi, pemeliharaan tubuh bibit, dan panen.

1. Persiapan Media (Substrat), adapun media tanam untuk jamur tiram adalah sebagai berikut: Serbuk gergaji kayu $=100 \mathrm{~kg}$, Dedak $=10 \mathrm{~kg}$, Kapur $=0,5 \mathrm{~kg}$, Tepung jagung = $0,5 \mathrm{~kg}$, Gula merah $=0,25 \mathrm{~kg}$, TSP (sebagai tambahan) $=0,25 \mathrm{~kg}$.

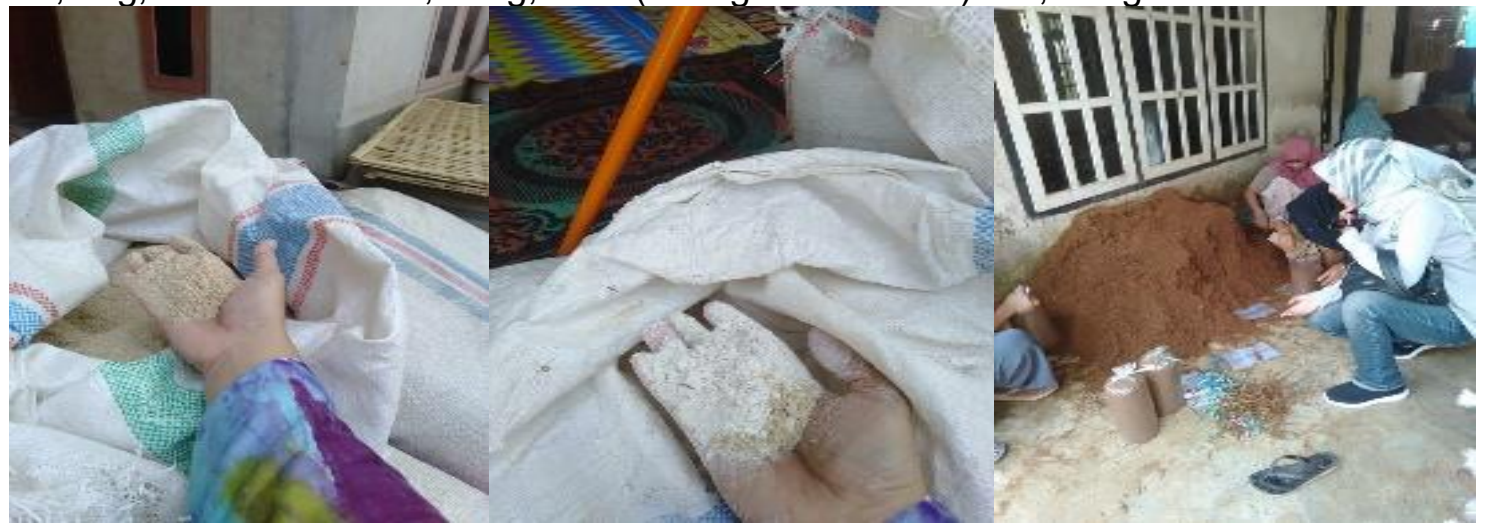

Gambar 3. Bahan Media Jamur Tiram (Dedak, Kapur dan Serbuk Kayu)

2. Pencampuran Media Tanam: Bahan media tanam yang telah disiapkan diaduk sampai rata agar pertumbuhan miselium dapat merata ke seluruh media tanam. Kemudian pengadukan dapat dilakukan dengan cara mekanis maupun secara manual. Apabila dilakukan secara manual upayakan pengadukan lebih lama sehingga diperoleh pencampuran yang merata terutama untuk bahan bahan yang konsentrasinya rendah. Media yang telah tercampur dengan baik biasanya menggumpal pada saat dikepal. Bila proses pencampuran dilakukan pengomposan (fermentasi) selama 3-5 hari. Proses 
pengomposan dapat membantu untuk mengurangi kontaminasi oleh mikroba liar dan juga membantu penguraian beberapa senyawa kompleks untuk menjadi lebih sederhana sehingga lebih mudah diserap oleh jamur tiram. pengadukan dilakukan setiap hari dengan tujuan proses pengomposan merata.

3. Pengantongan atau pembuatan baglog dilakukan dengan memasukkan media yang telah dikompos ke dalam plastik tahan panas dan diupayakan pengisian tidak terlalu longgar dan juga padat. Untuk memadatkan media dapat dilakukan dengan bantuan botol yang diisi dengan pasir. Setelah diisi media pada bagian atas lalu diberi ring bambu, leher botol, gulungan kertas, dan bisa juga pipa dan ditutup dengan kapas sebagai sebagai sumbu dan sekaligus tempat memasukkan bibit atau tempat keluarnya jamur setelah itu diikat dengan karet.

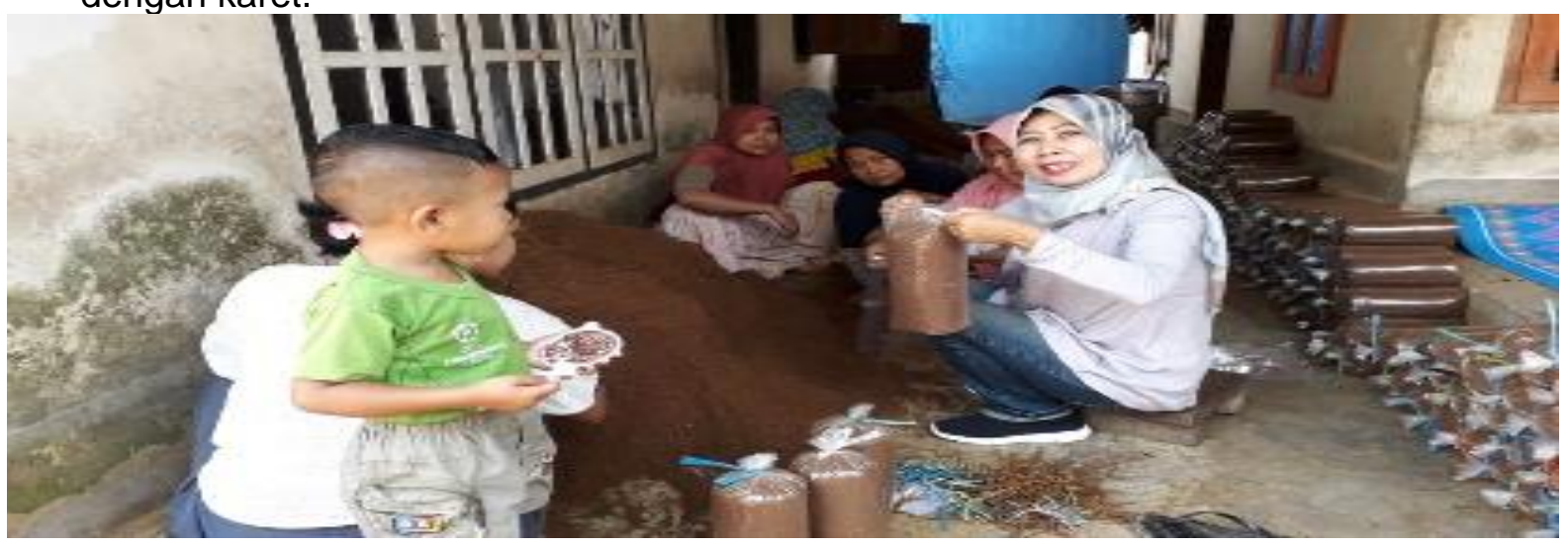

Gambar 4. Pemasukkan media ke baglog.

4. Sterilisasi baglog melalui proses pasteurisasi dengan cara dikukus. Pasteurisasiyaitu proses pemanasan dengan suhu tidak lebih dari $100^{\circ} \mathrm{C}$ dengan waktu tidakkurang dari 5 jam. Pada umumnya para produsen melakukan pemanasan selama 8-12 jam. Pemanasan ini tergantung pada bahan dasar yang digunakan danbanyaknya baglog yang dipasteurisasi. Setelah selesai baglog didinginkan selamasetengah sampai satu hari baru bisa digunakan.

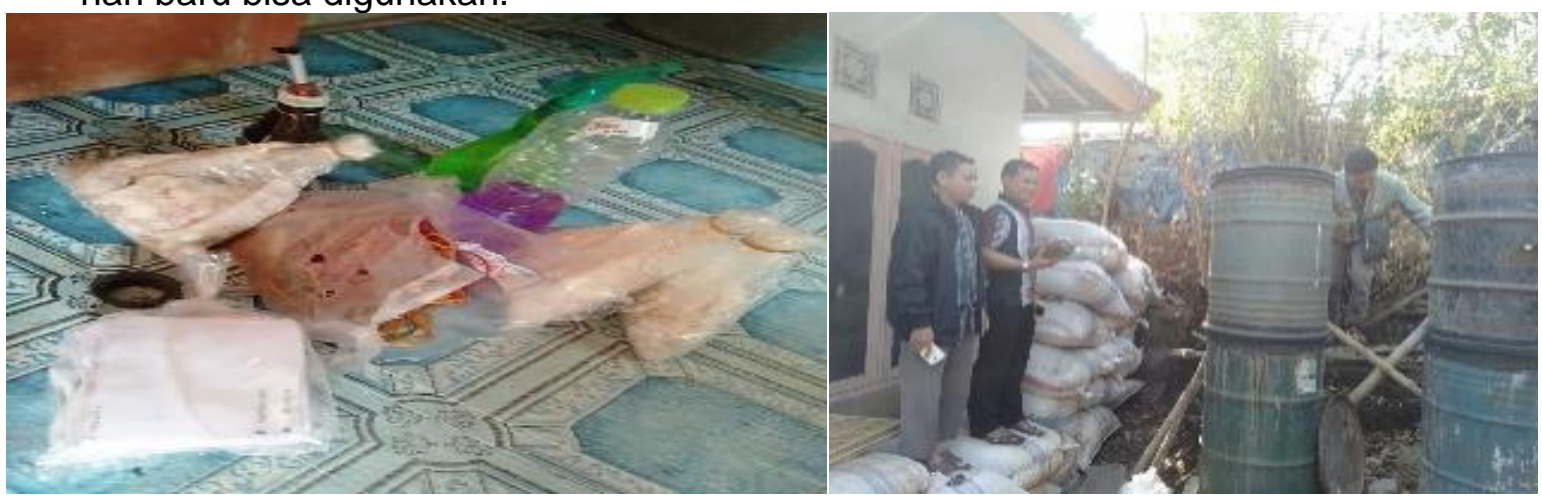

Gambar 5. bibit, bahan sterilisasi dan proses pengukusan

5. Inokulasi bibit merupakan proses penanaman bibit ke dalam media tanam. Proses inokulasi dilakukan secara steril. Ruangan diusahakan sebersih mungkin dan steril. Bila memungkinkan peralatan maupun ruangan disemprot alkohol terlebih dahulu. Selama proses ini disarankan menggunakan masker atau minimal tidak berbicara berlebihan untuk menghindari kontaminasi yang berasal dari uap mulut. Inokulasi dilakukan dengan memasukkan bibit (F2) sebanyak 2-5 sendok makan ke dalam lubang yang telah diberi pipa atau bisa juga dengan menebarkannya di atas permukaan media hingga merata kemudian menutup kembali lubang ring bambu dengan kapas.

6. Inkubasi merupakan masa pertumbuhan miselium hingga memenuhi media secara merata. Suhu yang dibutuhkan pada proses ini yaitu antara $22^{\circ} \mathrm{C}-28^{\circ} \mathrm{C}$. diupayakan suhu 
ruangan inkubasi dijaga agar tetap stabil sehingga dapat menghasilkan pertumbuhan jamur yang optimum. inkubasi dilakukan selama kurang lebih 40 hari.

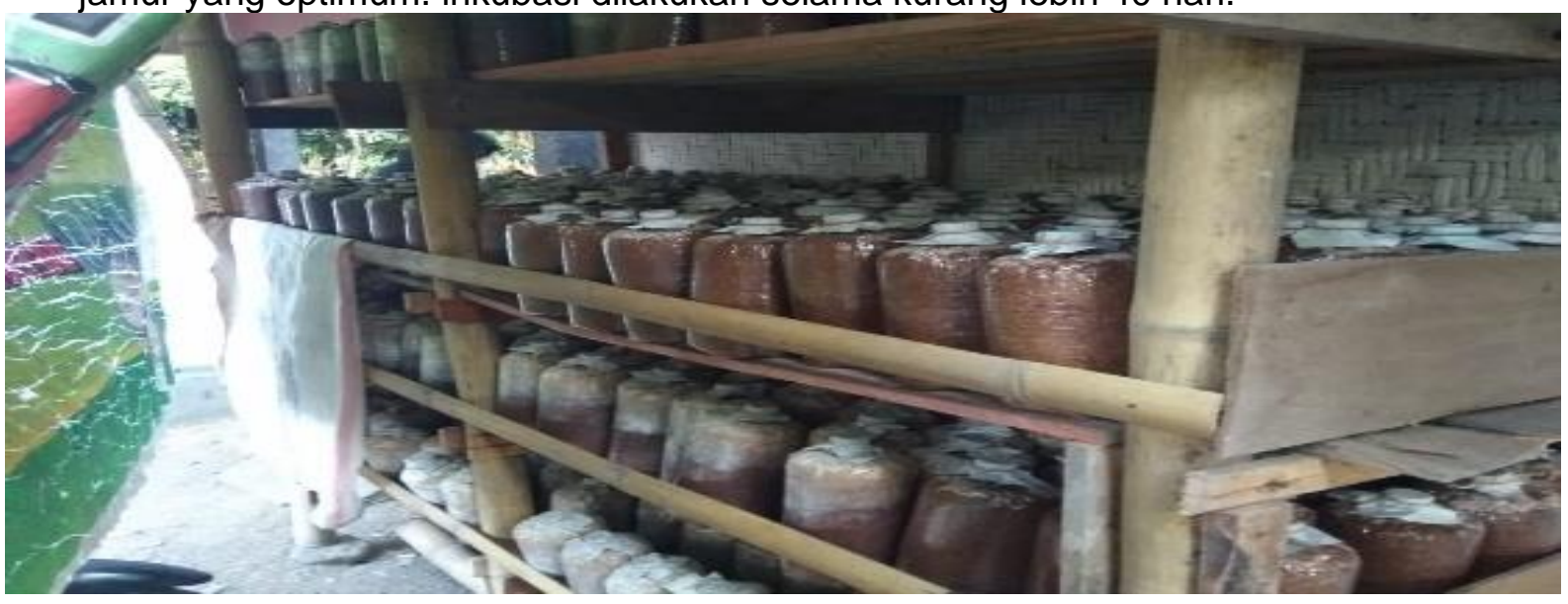

Gambar 6. Pemutihan Media

7. Pemeliharaan tubuh bibit. Pada masa pemeliharaan ini penutup baglog dibuka hingga seperempat bagian. Tahapan ini memerlukan suhu yang lebih rendah dibandingkan pada saat pertumbuhan miselium (tahap inkubasi) dan juga kelembapan yang optimum/berlimpah. Suhu yang diperlukan sekitar $20^{\circ} \mathrm{C}-26^{\circ} \mathrm{C}$ dengan kelembapan 80\%-90\% (Putra \& Hunaepi, 2014). Pengaturan kelembapan dapat dilakukan dengan penyiraman sebanyak 2-3 kali setiap hari terutama ketika kelembapan di luar rendah biasanya pada saat siang hari. Selain kelembapan, kadar oksigen juga perlu diatur dengan membuka ventilasi ketika kelembaban di luar tinggi. Kelembaban perlu dikurangi hingga $70 \%-80 \%$ apabila tubuh bibit telah mencapai ukuran dewasa. Hal ini dilakukan untuk menghindari tekstur tubuh bibit tidak lembek yang bisa menyebabkan tidak tahan lama atau cepat busuk.

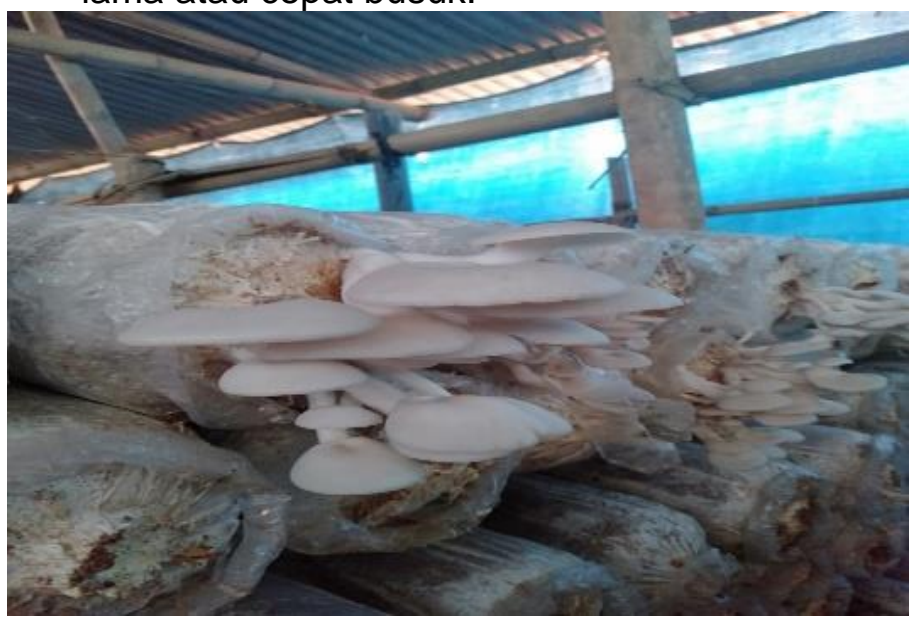

Gambar 7. Jamur mulai tumbuh

8. Panen dilakukan setelah 7-10 hari penutup dibuka, tubuh bibit biasanya sudah mulai tumbuh. Selang 3-4 hari setelah tunas tubuh bibit tumbuh, menunjukkanjamur telah siap dipanen. Pemanenan harus dilakukan dengan hati-hati dengancara mencabut seluruh rumpun tubuh bibit jamur yang ada beserta akarnya.Karena akar yang tertinggal bisa menyebabkan pertumbuhan tubuh bibitselanjutnya terganggu karena terjadi pembusukan media. Panen sebaiknyadilakukan pada pagi atau sore hari pada saat jamur masih dalam kondisi segar.Panen kedua biasanya berlangsung dalam rentang waktu 1-2 minggu setelahpanen pertama. Usia produktif berlangsung 3-4 bulan dengan produksi satubaglog sekitar $0,6 \mathrm{~kg}$. Setelah dilakukan pemanenan, log dipelihara seperti awalpenanaman yaitu dengan melakukan penyiraman, pengaturan suhu, kelembapanserta aerasi (Efendi, 2012). 


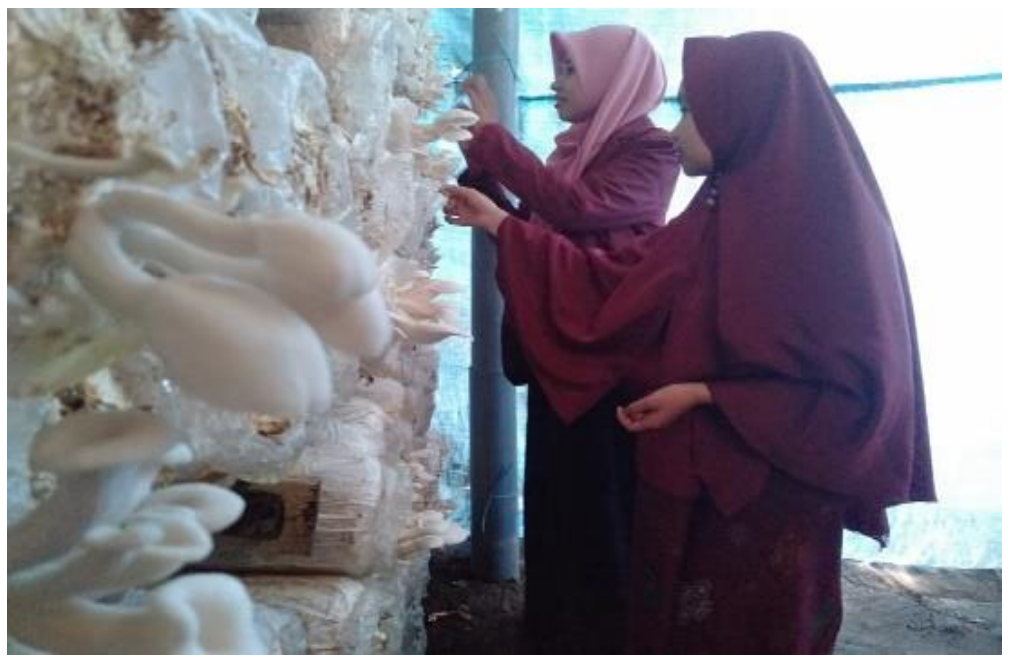

Gambar 8. Panen sebagian Jamur Tiram

Hasil Pengabdian program KKN-PPM ini adalah terbentuknya 2 kumbung (rumah jamur) dan kelompok budidaya jamur tiram di Desa sukarara kabupaten Lombok Timur. Masyarakat di Desa Sukarara khususnya kelompok tani sebelumnya tidak pernah melakukan budidaya jamur tiram. Dengan adanya program KKN-PPM tentang budidaya jamur tiram, maka masyarakat desa Sukarara khususnya kelompok tani sudah mampu mengembangkan budidaya jamur tiram, mulai mempersiapkan bahan, memberikan baglog kepada masing masing kelompok (@1500 Baglog) dan sebagian membuat baglog, isolasi, inokulasi, pemanenan dan pemasaran.

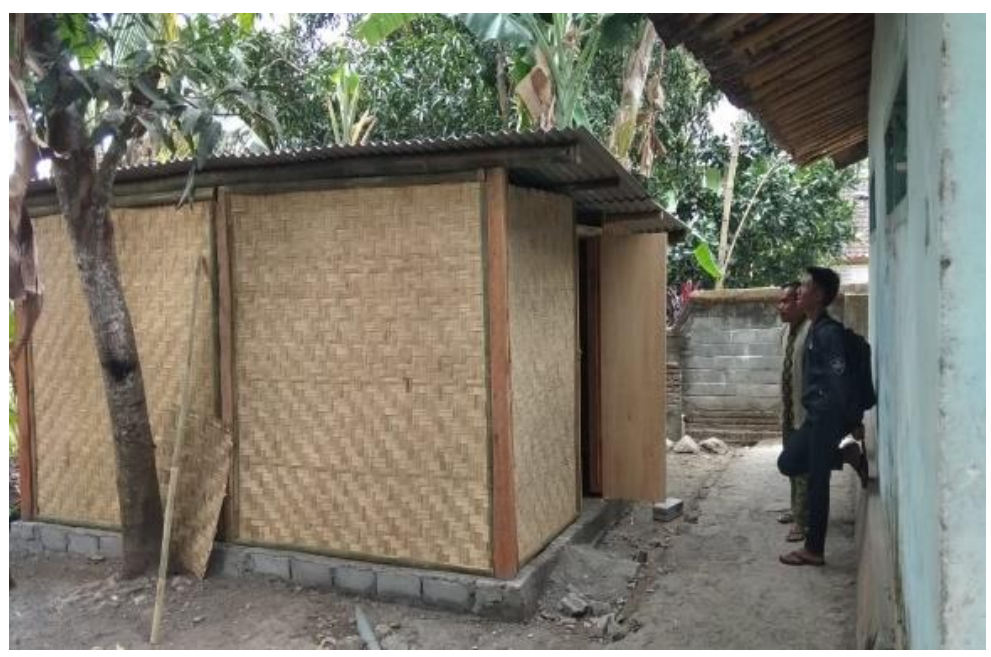

Gambar 10. Kumbung (Rumah Jamur)

\section{KESIMPULAN}

Program KKN-PPM yang dilaksakana berhasil dengan indikator terbentuknya 1) pemahaman mitra tentang pemanfaatan limbah serbuk gergaji sebagai bahan dasar media tanam jamur tiram, dan 2) terbentuknya keterampilan mitra dalam pembudidayaan jamur tiram.

\section{DAFTAR PUSTAKA}

Achmad,E.N. Herliyana, I.Z. Siregar, dan O. Permana (2011) Karakter Morfologis dan Genetik Jamur Tiram (Pleurotus spp.) . Jurnal Hort. 21 (3):225-231.

Efendi, I. 2012. Pembudidayaan Jamur Tiram. Mataram: Jakamandala.

Efendi I. (2018) Modul 1: Sekilas Budidaya Jamur Tiram. (tidak dipublikasi) Program Studi Pendidikan Biologi. FPMIPA IKIP Mataram 
Hunaepi, Samsuri, T., Asy'ari, M., Mirawati, B., Firdaus, L. (2019). Budidaya Jamur Tiram di Pondok Pesantren Hidayaturrahman NW Manggala. Sasambo: Jurnal Abdimas (Journal of Community Service), 1(1), 45-52. doi: 10.36312/sasambo.v1i1.119

Tim Penyusun Pedoman KKN-PPL UNW Mataram. 2019. Pedoman KKN-PPL Terpadu UNW Mataram. Mataram; UNW Mataram.

Putra, D.M.G., dan Hunaepi (2014) pengaruh penggunaan evaporative pad terhadap iklim mikro pada rumah jamur tiram (pleurotus ostreatus)berdinding jerami di musim kemarau. Jurnal Ilmiah Biologi Bioscientist. Vol. 2. No. 1. 88-99.

Sunarmi, I.Y., dan Suparito, C. (2018) Usaha 4 Jenis Jamur sekala Rumah tangga: Jamur tiram, Jamur Kuping, Jamur merang, Jamur Champignon (kancng). Penebar Suadaya. Jakarta Timur.

Suryani T \& Carolina H. (2017) Pertumbuahn dna hasil jamur tiram putih pada beberapa bahan media pembibitan. Bioekperimen 3(1) 73-86 DOI: https://doi.org/10.23917/bioeksperimen.v3i1.3674

http://www.wikiwand.com/id/Sukarara, Lombok Timur. Diakses tanggal 20 Mei 2017 